DOI: $10.15193 /$ zntj/2017/111/190

\author{
IZABELA PODGÓRSKA, EWA SOLARSKA
}

\title{
OCENA JAKOŚCI MIKROBIOLOGICZNEJ HERBAT ZIOLOWYCH W SASZETKACH
}

\begin{abstract}
Streszczenie
Celem badań było określenie mikrobiologicznego zanieczyszczenia herbat ziołowych w saszetkach, dostępnych w placówkach sprzedaży detalicznej w Lublinie oraz określenie składu jakościowego występujących w nich grzybów mitosporowych. Badaniami objęto 7 rodzajów herbat ziołowych z takich surowców, jak: melisa, pokrzywa, mięta, koper włoski, lipa, rumianek oraz szałwia. W przeprowadzonym doświadczeniu oznaczono ogólną liczbę bakterii, drożdży, grzybów mitosporowych i bakterii z gatunku Escherichia coli oraz wykonano analizę na obecność pałeczek Salmonella i gronkowców koagulazododatnich. Stwierdzono, że ogólna liczba bakterii mezofilnych tlenowych, drożdży i grzybów mitosporowych mieściła się $\mathrm{w}$ zakresie odpowiednio $\left[\mathrm{jtk} \cdot \mathrm{g}^{-1}\right.$ ]: $10^{3} \div 10^{7}, 10^{3} \div 10^{4}$ oraz $10^{2} \div 10^{5}$. Herbaty ziołowe w saszetkach zawierające pokrzywę oraz miętę były najbardziej zanieczyszczone przez bakterie i grzyby mitosporowe. Nie spełniały one wymagań czystości mikrobiologicznej zawartych w Farmakopei Polskiej (wyd. X). Skład jakościowy grzybów mitosporowych w badanych suszach roślinnych był zróżnicowany, należały one łącznie do 10 rodzajów, takich jak: Alternaria, Aspergillus, Botrytis, Cladosporium, Fusarium, Mucor, Penicillium, Phoma, Rhizopus, Trichoderma. We wszystkich ocenianych próbach herbat ziołowych największy udział miały grzyby z rodzajów Aspergillus, Fusarium i Penicillium. Zastrzeżenia budził stan sanitarno-higieniczny herbat z suszu pokrzywy i mięty, w których wykryto skażenie przez bakterie $E$. coli na poziomie $10^{2} \mathrm{jtk} \cdot \mathrm{g}^{-1}$. W żadnej z badanych prób nie stwierdzono natomiast obecności bakterii Salmonella oraz gronkowców koagulazododatnich.
\end{abstract}

Słowa kluczowe: zioła suszone, jakość mikrobiologiczna, bakterie, drożdże, grzyby mitosporowe

\section{Wprowadzenie}

Susze roślinne to bogaty asortyment produktów, takich jak przyprawy, używki i zioła, które cechują się małą zawartością wody oraz zróżnicowaną mikroflorą. $\mathrm{Na}$ rodzaj mikroflory obecnej w ziołach wpływ ma organ rośliny wykorzystywany do

Mgr inż. I. Podgórska, prof. dr hab. E. Solarska, Katedra Biotechnologii, Żywienia Człowieka i Towaroznawstwa Żywności, Wydz. Nauk o Żywności i Biotechnologii, Uniwersytet Przyrodniczy w Lublinie, ul. Skromna 8, 20-704 Lublin. Kontakt:izapodg@gmail.com 
suszenia. Zanieczyszczenie mikrobiologiczne jest bowiem skutkiem odmiennego kontaktu każdej części rośliny ze środowiskiem zewnętrznym podczas uprawy oraz możliwości wtórnego zanieczyszczenia mikrobiologicznego w czasie suszenia i składowania [18]. Nieodpowiednie metody uprawy i zbioru roślin, następnie ich niewłaściwe suszenie, przedłużone magazynowanie oraz nieprzestrzeganie zasad higieny w czasie przetwarzania suszy roślinnych mogą prowadzić do mikrobiologicznego zanieczyszczenia ziół. Susze ziołowe mogą być zanieczyszczone przez szeroką gamę mikroorganizmów, takich jak bakterie, drożdże i liczne gatunki grzybów mitosporowych, które są odpowiedzialne za psucie surowców i produkcję niebezpiecznych mikotoksyn. Wzrost wykorzystania suszonych ziół może prowadzić zatem do zwiększenia spożycia mikotoksyn, a tym samym przyczyniać się do pogorszenia stanu zdrowia ludzi [2, 19]. Wielu autorów stwierdza występowanie na ziołach głównie grzybów z rodzajów Aspergillus i Penicillium, którym przypisuje się największą szkodliwość. Liczne badania wskazują też na duży stopień zanieczyszczenia ziół przez grzyby z rodzajów: Alternaria, Cladosporium, Rhizopus, Mucor, Fusarium, Septoria czy Verticillium [3, 4, 15, 21].

Rośliny od wieków stosowane są w terapii wielu schorzeń na całym świecie i odgrywają ważną rolę w tradycyjnej medycynie. Suszone zioła czy leki roślinne nie powinny być postrzegane jako proste narzędzie medycyny naturalnej, ponieważ są one klasą produktów, które muszą spełniać określone wymagania pod względem jakości, bezpieczeństwa i skuteczności działania. Herbaty ziołowe niespełniające wymagań jakościowych w aspekcie czystości mikrobiologicznej i bezpieczeństwa zdrowotnego mogą wpływać negatywnie na organizm.

Celem niniejszej pracy była ocena czystości mikrobiologicznej wybranych herbat ziołowych w saszetkach, dostępnych w placówkach sprzedaży detalicznej oraz określenie składu jakościowego występujących w nich grzybów mitosporowych.

\section{Material i metody badań}

Materiał do badań stanowiło 7 rodzajów herbat ziołowych w saszetkach dostępnych w obrocie handlowym, tj. melisa, pokrzywa, mięta, koper włoski, lipa, rumianek oraz szałwia. Wszystkie herbaty pochodziły od tego samego producenta, zakupiono je w różnych placówkach handlu detalicznego w Lublinie, a zakupu dokonano w jednym terminie. Dany rodzaj herbaty ziołowej reprezentowały 3 opakowania jednej partii produkcyjnej. Wszystkie herbaty ziołowe w oryginalnych pudełkach zawierały po 20 saszetek. Z każdego opakowania odważono sterylnie $10 \mathrm{~g}$ ziół wydobytych z saszetki do kolby z $90 \mathrm{~cm}^{3}$ płynu do rozcieńczeń zawierającego $\mathrm{NaCl}$ i pepton. Zawartość kolb wytrząsano 2 min i uzyskiwano w ten sposób rozcieńczenie wyjściowe, a następnie sporządzano kolejne rozcieńczenia dziesięciokrotne. 
Analiza mikrobiologiczna herbat ziołowych w saszetkach obejmowała: ogólną liczbę bakterii mezofilnych tlenowych - według PN-ISO 4833:2004 [13], liczbę drożdży i grzybów mitosporowych - według PN-ISO 21527-2:2009 [12], liczbę bakterii Escherichia coli - według PN ISO 16649-2:2004 [10], obecność pałeczek Salmonella sp. - według PN-ISO 6579:2003 [14] i gronkowców koagulazododatnich - według PN-EN ISO 6888-1:2001 [11]. Ponadto na podstawie cech makro- i mikroskopowych kolonii $[8,17,20]$ określano skład jakościowy grzybów mitosporowych wyizolowanych z badanych próbek herbat ziołowych.

Posiewy przeprowadzano $\mathrm{w}$ trzech powtórzeniach, przy czym jedno powtórzenie stanowił posiew z jednej naważki z opakowania danego rodzaju herbaty, następnie obliczano średnią arytmetyczną. Liczbę drobnoustrojów wyrażano jako jednostki tworzące kolonie w $1 \mathrm{~g}$ produktu [jtk $\cdot \mathrm{g}^{-1}$ ]. W pracy wyniki dotyczące liczby drobnoustrojów przedstawiono w postaci logarytmicznej - log $\mathrm{jtk} \cdot \mathrm{g}^{-1}$.

\section{Wyniki i dyskusja}

Wyniki oceny zanieczyszczenia mikrobiologicznego badanych herbat ziołowych przez bakterie, drożdże i grzyby mitosporowe zamieszczono w tab. 1. Poszczególne rodzaje herbat ziołowych różniły się między sobą zanieczyszczeniem przez mikroorganizmy. Liczba bakterii mezofilnych tlenowych zawierała się $\mathrm{w}$ przedziale od $3,92 \log \mathrm{jtk} \cdot \mathrm{g}^{-1}\left(8,3 \times 10^{3} \mathrm{jtk} \cdot \mathrm{g}^{-1}\right)$ w lipie do $7,62 \mathrm{log} \mathrm{jtk} \cdot \mathrm{g}^{-1}\left(4,2 \times 10^{7} \mathrm{jtk} \cdot \mathrm{g}^{-1}\right)$ w pokrzywie. W badanym materiale liczba drożdży wahała się od $2,11 \log \mathrm{jtk} \cdot \mathrm{g}^{-1}$ $\left(1,3 \times 10^{2} \mathrm{jtk} \cdot \mathrm{g}^{-1}\right)$ w melisie do 4,92 log $\mathrm{jtk} \cdot \mathrm{g}^{-1}\left(8,4 \times 10^{4} \mathrm{jtk} \cdot \mathrm{g}^{-1}\right)$ w mięcie. Liczba grzybów mitosporowych wynosiła od 2,68 $\log \mathrm{jtk} \cdot \mathrm{g}^{-1}\left(4,8 \times 10^{2} \mathrm{jtk} \cdot \mathrm{g}^{-1}\right) \mathrm{w}$ lipie do $5,54 \log \mathrm{jtk} \cdot \mathrm{g}^{-1}\left(3,5 \times 10^{5} \mathrm{jtk} \cdot \mathrm{g}^{-1}\right) \mathrm{w}$ mięcie.

$\mathrm{W}$ tab. 2. przedstawiono skład jakościowy grzybów mitosporowych wyizolowanych $\mathrm{z}$ ocenianych herbat ziołowych $\mathrm{w}$ saszetkach. Grzyby mitosporowe obecne w badanym materiale należały łącznie do 10 rodzajów: Alternaria, Aspergillus, Botrytis, Cladosporium, Fusarium, Mucor, Penicillium, Phoma, Rhizopus, Trichoderma. Stwierdzono, że najbardziej zróżnicowany był skład jakościowy grzybów herbat z mięty i pokrzywy. We wszystkich badanych herbatach ziołowych w saszetkach stwierdzono obecność grzybów mitosporowych z trzech rodzajów: Aspergillus, Fusarium, Penicillium.

Stan sanitarno-higieniczny herbat ziołowych jest ważny z uwagi na bezpieczeństwo zdrowotne konsumentów. Wykazano (tab. 3), że w próbkach herbat z pokrzywy i mięty wykryto zanieczyszczenie bakteriami $E$. coli. W żadnej z badanych próbek nie występowały natomiast pałeczki Salmonella sp. oraz gronkowce koagulazododatnie. 
Tabela 1. Ogólna liczba bakterii mezofilnych tlenowych, drożdży i grzybów mitosporowych w badanych herbatach ziołowych w saszetkach

Table 1. Total count of mesophilic aerobic bacteria, yeasts, and mitosporic fungi in herbal tea tested

\begin{tabular}{|l|c|c|c||}
\hline \multicolumn{1}{|c|}{$\begin{array}{c}\text { Herbata ziołowa } \\
\text { Herbal tea }\end{array}$} & $\begin{array}{c}\text { Ogólna liczba bakterii } \\
{\left[\log \mathrm{jtk} \cdot \mathrm{g}^{-1}\right]} \\
\text { Total count of bacteria } \\
{\left[\log \mathrm{cfu} \cdot \mathrm{g}^{-1}\right]}\end{array}$ & $\begin{array}{c}\text { Drożdże }\left[\log \mathrm{jtk} \cdot \mathrm{g}^{-1}\right] \\
\text { Yeast }\left[\operatorname{log~} \mathrm{cfu} \cdot \mathrm{g}^{-1}\right]\end{array}$ & $\begin{array}{c}\text { Grzyby mitosporowe } \\
{\left[\log \mathrm{jtk} \cdot \mathrm{g}^{-1}\right]} \\
\text { Mitosporic fungi } \\
{\left[\log \mathrm{cfu} \cdot \mathrm{g}^{-1}\right]}\end{array}$ \\
\hline Melisa / Lemon balm & $5,46 \pm 0,082$ & $2,11 \pm 0,115$ & $4,49 \pm 0,227$ \\
\hline Pokrzywa / Nettle & $7,62 \pm 0,321$ & $4,43 \pm 0,445$ & $5,04 \pm 0,267$ \\
\hline Mięta / Mint & $7,46 \pm 0,236$ & $4,92 \pm 0,183$ & $5,54 \pm 0,255$ \\
\hline Koper włoski / Fennel & $4,63 \pm 0,173$ & $2,94 \pm 0,226$ & $3,32 \pm 0,199$ \\
\hline Lipa / Linden & $3,92 \pm 0,165$ & $2,81 \pm 0,132$ & $2,68 \pm 0,151$ \\
\hline Rumianek / Chamomile & $4,61 \pm 0,108$ & $3,64 \pm 0,435$ & $4,58 \pm 0,211$ \\
\hline Szałwia / Sage & $4,51 \pm 0,282$ & $2,88 \pm 0,174$ & $3,04 \pm 0,197$ \\
\hline
\end{tabular}

Objaśnienie / Explanatory note:

W tabeli przedstawiono wartości średnie \pm odchylenia standardowe / Table shows mean values and standard deviations; $\mathrm{n}=3$.

Tabela 2. Skład jakościowy grzybów mitosporowych w badanych herbatach ziołowych w saszetkach Table 2. Qualitative composition of mitosporic fungi in herbal tea tested

\begin{tabular}{|c|c|c|c|c|c|c|c|}
\hline \multirow{2}{*}{$\begin{array}{l}\text { Wyizolowany } \\
\text { grzyb mitosporowy } \\
\text { Isolated mitosporic } \\
\quad \text { fungi }\end{array}$} & \multicolumn{7}{|c|}{$\begin{array}{l}\text { Procentowy udział w ogólnej liczbie grzybów wyizolowanych } \\
\text { z badanych herbat ziołowych } \\
\text { Percentage content in total count of isolated mitosporic fungi from herbal tea }\end{array}$} \\
\hline & $\begin{array}{l}\text { Melisa } \\
\text { Lemon } \\
\text { balm }\end{array}$ & $\begin{array}{c}\text { Pokrzywa } \\
\text { Nettle }\end{array}$ & $\begin{array}{l}\text { Mięta } \\
\text { Mint }\end{array}$ & $\begin{array}{c}\text { Koper włoski } \\
\text { Fennel }\end{array}$ & $\begin{array}{l}\text { Lipa } \\
\text { Linden }\end{array}$ & $\begin{array}{l}\text { Rumianek } \\
\text { Camomile }\end{array}$ & $\begin{array}{c}\text { Szałwia } \\
\text { Sage }\end{array}$ \\
\hline Alternaria sp. & 14,6 & 12,4 & 11,7 & 15,3 & - & - & - \\
\hline Aspergillus sp. & 31,9 & 20,1 & 18,8 & 27,3 & 42,3 & 26,8 & 32,8 \\
\hline Botrytis sp. & - & 6,8 & 9,7 & 7,6 & - & 12,7 & - \\
\hline Cladosporium sp. & 9,7 & - & 6,1 & - & - & - & - \\
\hline Fusarium sp. & 14,1 & 15,6 & 13,7 & 19,3 & 20,2 & 24,9 & 25,6 \\
\hline Mucor sp. & - & 5,1 & 3,9 & - & - & - & - \\
\hline Penicillium sp. & 29,7 & 26,1 & 19,5 & 30,5 & 37,5 & 27,3 & 41,6 \\
\hline Phoma sp. & - & 4,6 & 5,6 & - & - & - & - \\
\hline Rhizopus sp. & - & 9,3 & 7,1 & - & - & - & - \\
\hline Trichoderma sp. & - & - & 3,9 & - & - & 8,3 & - \\
\hline
\end{tabular}

Herbaty ziołowe pod względem czystości mikrobiologicznej powinny odpowiadać wymaganiom zatwierdzonym przez określone normy producenta. W badaniach własnych oceniano produkty ziołowe przeznaczone do przygotowywania naparów z użyciem wrzącej wody. Według wymagań Farmakopei Polskiej, wyd. X [6], w takich 
produktach ogólna liczba drobnoustrojów tlenowych powinna być nie większa niż $10^{7} \mathrm{jtk} \cdot \mathrm{g}^{-1}$, ogólna liczba pleśni i drożdży nie większa niż $10^{5} \mathrm{jtk} \cdot \mathrm{g}^{-1}$, a liczba bakterii E. coli nie większa niż $10^{3} \mathrm{jtk} \cdot \mathrm{g}^{-1}$. W przeprowadzonych badaniach własnych podanych wymagań nie spełniły herbaty ziołowe w saszetkach, zawierające pokrzywę i miętę.

Tabela 3. Wskaźniki sanitarno-higieniczne badanych herbatach ziołowych w saszetkach Table 3. Hygienic parameters of herbal tea tested

\begin{tabular}{|c|c|c|c|}
\hline $\begin{array}{c}\text { Herbata ziołowa } \\
\text { Herbal tea }\end{array}$ & $\begin{array}{c}\text { E. coli } \\
{\left[\log \mathrm{jtk} \cdot \mathrm{g}^{-1}\right]} \\
{\left[\log \mathrm{cfu} \cdot \mathrm{g}^{-1}\right]}\end{array}$ & $\begin{array}{l}\text { Salmonella sp. } \\
\qquad\left[\begin{array}{ll}2 & 25 \\
\mathrm{~g}\end{array}\right] \\
{[\text { in } 25 \mathrm{~g}]}\end{array}$ & $\begin{array}{c}\text { Gronkowce koagulazododatnie } \\
\text { Staphylococci coagulase }(+) \\
{\left[\begin{array}{lll}\mathrm{w} & 1 & \mathrm{~g}\end{array}\right] /\left[\begin{array}{lll}\text { in } & 1 & \mathrm{~g}\end{array}\right]}\end{array}$ \\
\hline Melisa / Lemon balm & - & - & - \\
\hline Pokrzywa / Nettle & 2,51 & - & - \\
\hline Mięta / Mint & 2,44 & - & - \\
\hline Koper włoski / Fennel & - & - & - \\
\hline Lipa / Linden & - & - & - \\
\hline Rumianek / Chamomile & - & - & - \\
\hline Szałwia / Sage & - & - & - \\
\hline
\end{tabular}

Objaśnienie / Explanatory note:

$(-)$ - nieobecne / absent.

Spośród ocenianych w pracy herbat ziołowych największym zanieczyszczeniem przez bakterie odznaczały się produkty z pokrzywy $\left(4,2 \times 10^{7} \mathrm{jtk} \cdot \mathrm{g}^{-1}\right)$ oraz mięty $(2,9 \times$ $\left.10^{7} \mathrm{jtk} \cdot \mathrm{g}^{-1}\right)$. Podobne wyniki otrzymali Wilson i wsp. [23], którzy stwierdzili największą liczbę bakterii w herbatach ziołowych $\mathrm{z}$ rumianku i mięty. Badania tych autorów obejmowały napary z ziół zalewanych wodą o temp. 90 i $67{ }^{\circ} \mathrm{C}$. Wszystkie napary sporządzone $\mathrm{w}$ temp. $90{ }^{\circ} \mathrm{C}$ były zanieczyszczone niefermentującymi bakteriami Gram-ujemnymi, należącymi do gatunków Acinetobacter baumannii oraz Pseudomonas aeruginosa. Temperatura parzenia $67{ }^{\circ} \mathrm{C}$ nie była wystarczająca, aby zniszczyć bakterie - liczba drobnoustrojów tlenowych w naparach sporządzonych w tej temperaturze zawierała się w przedziale $3,8 \times 10^{3} \div 1,6 \times 10^{6} \mathrm{jtk} \cdot \mathrm{ml}^{-1}$. W badaniach ziół pochodzących z obrotu handlowego Martins i wsp. [9] stwierdzili występowanie bakterii Bacillus cereus we wszystkich badanych próbkach rumianku, lipy i mięty, a ich obecności nie wykryli jedynie w próbkach szałwii. We wszystkich ziołach badanych przez tych autorów [9], tj. w rumianku, lipie, mięcie i szałwii, występowały także bakterie Clostridium perfringens.

W przeprowadzonych badaniach zanieczyszczenie przez chorobotwórcze bakterie Escherichia coli stwierdzono tylko w próbkach pokrzywy i mięty. Podobne wyniki dotyczące występowania chorobotwórczych bakterii, w tym E. coli, m.in. w liściach mięty, pokrzywy oraz w zielu skrzypu odnotowali Stević i wsp. [19]. Wilson i wsp. [23] wykazali obecność bakterii E. coli, Enterococcus faecalis oraz Acinetobacter 
baumannii i Pseudomonas aeruginosa w herbatach z kopru oraz rumianku. Występowanie bakterii $E$. coli w suszonych ziołach może być wynikiem zanieczyszczenia podczas ich uprawy lub też nieprzestrzegania zasad higieny na etapie przetwarzania surowców. Zanieczyszczenie ziół przez drobnoustroje chorobotwórcze, takie jak: Salmonella sp., Shigella sp., Listeria monocytogenes i Vibrio sp. jest rzadko odnotowywane w literaturze przedmiotu, jednak zdarza się. W Niemczech na przykład w okresie od października 2002 do lipca 2003 stwierdzono, że wśród niemowląt w wieku poniżej 13 miesięcy wystąpiły zatrucia pokarmowe spowodowane wypiciem zanieczyszczonych przez Salmonella enterica herbat ziołowych, zawierających anyż, koper włoski i kminek [7].

Istotnym problemem mikrobiologicznego stanu ziół jest ich zanieczyszczenie przez grzyby mitosporowe. Należy podkreślić, że grzyby należące do rodzajów Aspergillus, Penicillium i Fusarium, najliczniej występujące we wszystkich badanych $\mathrm{w}$ tej pracy ziołach, stanowią poważne zagrożenie dla jakości i bezpieczeństwa surowców ze względu na możliwość wytwarzania mikotoksyn. Grzyby z rodzajów Penicillium i Aspergillus mogą produkować liczne mikotoksyny - oprócz ochratoksyny A i aflatoksyny także: patulinę, cytryninę, cytreowirydynę, rubratoksynę, kwas penicylinowy, kwas cyklopiazonowy, kwas mykofenolowy [5, 16, 19]. Grzyby z rodzaju Aspergillus zdolne są do wzrostu przy małej zawartości wody, dlatego, aby nie dopuścić do ich rozwoju i ewentualnego tworzenia toksycznych metabolitów, surowiec zielarski powinien być wysuszony możliwie szybko. Natomiast zarodniki grzybów z rodzaju Fusarium potrafią przetrwać warunki suszenia i grzyb ten może pozostać na surowcach roślinnych w „uśpieniu” przez wiele miesięcy, a nawet lat. Jeżeli w tym czasie wilgotność produktu wzrośnie do poziomu pozwalającego na kiełkowanie zarodników, może spowodować rozwój grzybni i produkcję mikotoksyn [19].

Przeprowadzone badania potwierdziły wyniki innych naukowców, którzy również stwierdzili w suszonych ziołach dominację grzybów z rodzajów Aspergillus, Penicillium i Fusarium. Bugno i wsp. [3] wykazali, że dominującymi grzybami izolowanymi z ziół, m.in. z melisy, lipy, rumianku, kopru włoskiego, skrzypu czy anyżu były gatunki: Aspergillus flavus (23,39 \%), Aspergillus niger (20,97\%) i Penicillium citrinum (12,50\%), jak również Aspergillus ochraceus (10,48 \%), Penicillium chrysogenum $(5,24 \%)$ i Aspergillus parasiticus (4,44\%). Z kolei Rizzo i wsp. [15] w badaniach suszonych ziół wykazali zanieczyszczenie melisy przez Aspergillus flavus, A. sojae, Fusarium verticillioides i $F$. equiseti, suszonej mięty - przez A. flavus i $F$. equiseti, a rumianku przez A. flavus i $F$. compactum. Również Alwakeel [1] w dostępnych na rynku suszonych ziołach stwierdził powszechne występowanie grzybów z rodzajów Aspergillus i Penicillium. Z rumianku został wyizolowany toksynotwórczy grzyb $A$. flavus, z kopru A. fumigatus i $P$. citrinum, natomiast z szałwii A. fumigatus i $A$. ochraceus. Tournas i Katsoudas [22] przeprowadzili badania dotyczące jakości mikrobiolo- 
gicznej różnych herbat ziołowych i dowiedli, że największą częstotliwością występowania odznaczał się $A$. niger, który stwierdzono w $50 \%$ prób rumianku. Herbata $\mathrm{z}$ rumianku charakteryzowała się największym zanieczyszczeniem grzybami mitosporowymi $\left(5,8 \times 10^{5} \mathrm{jtk}^{-\mathrm{g}^{-1}}\right)$, a w ich składzie, oprócz A. niger, były też obecne: A. flavus, A. ochraceus, Penicillium sp., Eurotium chevalieri, Eurotium rubrum, Alternaria alternata, Rhizopus sp. Martins i wsp. [9] badali zioła pochodzące z obrotu handlowego (m.in. rumianek, lipę, miętę i szałwię) i stwierdzili występowanie grzybów mitosporowych w 93,5 \% prób. W większości były to gatunki z rodzaju Aspergillus: A. niger, A. glaucus, A. flavus, A fumigatus, A. candidus, A. terreus, A. flavipes oraz liczne izolaty z rodzajów Penicillium, Fusarium, Cladosporium, Mucor, Absidia, Paecilomyces.

$\mathrm{W}$ przeprowadzonych badaniach własnych wykazano, że herbata miętowa w saszetkach charakteryzowała się największym zanieczyszczeniem przez drożdże $(8,4 \times$

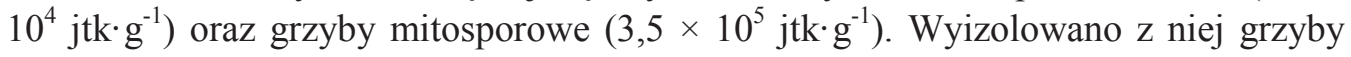
z rodzajów Penicillium (19,5\%), Aspergillus (18,8 \%), Fusarium (13,7 \%), Alternaria (11,7 \%), Botrytis (9,7 \%), Rhizopus (7,1 \%), Cladosporium (6,1 \%), Phoma (5,6 \%), Mucor (3,9\%), Trichoderma (3,9\%). Podobne rezultaty w 2-letnich badaniach suszonych roślin leczniczych uzyskali wcześniej Stević i wsp. [19], którzy największe zanieczyszczenie mikrobiologiczne również wykazali w mięcie. Liczba obecnych w niej grzybów mitosporowych przekraczała $10^{6} \mathrm{jtk} \cdot \mathrm{g}^{-1}$ i oprócz najczęściej występujących grzybów Fusarium sp. i Aspergillus sp. zidentyfikowali także: Alternaria alternata, Phoma sp., Penicillium sp., Cladosporium sp., Cercospora sp, Phomopsis sp, Verticillium dahliae, V. cynobarium, Bipolaris tetramera, Rhizoctonia solani, Septoria sp., Trichoderma viride, Curvularia lunata, Gliocladium sp., Rhizopus sp., Mucor sp. W badaniach tych [19] aż 74 \% próbek mięty było skażonych przez grzyby mitosporowe, natomiast $\mathrm{w}$ mniejszym stopniu grzyby te zanieczyszczały próbki pokrzywy (56\%), rumianku (47\%), lipy (40\%) i melisy (38 \%). Tournas i Katsoudas [22] również wykazali duże zanieczyszczenie herbaty miętowej przez grzyby mitosporowe i stwierdzili występowanie Aspergillus sp. i A. alternata na poziomie sięgającym odpowiednio $5,5 \times 10^{4} \mathrm{i} 7,4 \times 10^{4} \mathrm{jtk} \cdot \mathrm{g}^{-1}$, a Phoma sp. w liczbie $1,0 \times 10^{4} \mathrm{jtk} \cdot \mathrm{g}^{-1}$. Drożdże wykryto w $33 \%$ próbek mięty, a ich średnia liczba wynosiła $4,8 \times 10^{3} \mathrm{jtk} \cdot \mathrm{g}^{-1}$. Przyczynę takiego skażenia mięty autorzy upatrują w dużej higroskopijności liści tej rośliny i w konsekwencji w większym ich narażeniu na zanieczyszczenie przez mikroorganizmy. Dlatego szybkie wysuszenie ziół zaraz po zbiorach jest niezbędne. W celu zminimalizowania ryzyka dalszego wtórnego zanieczyszczenia konieczna jest także rygorystyczna kontrola warunków zewnętrznych, tj. temperatury i wilgotności na wszystkich etapach produkcji i magazynowania.

Przedstawione powyżej wyniki badań czystości mikrobiologicznej mięty suszonej odniesiono do wyników badań świeżej mięty uzyskanych przez Wójcik-Stopczyńską i wsp. [24]. Odnotowano, że mikroorganizmy w świeżej mięcie reprezentowane były 
głównie przez grzyby Alternaria sp., Cladosporium sp. oraz Botrytis sp., natomiast rzadziej niż z mięty suszonej izolowano grzyby z rodzajów Fusarium, Penicillium i Aspergillus, co wskazuje na wzrost zanieczyszczenia mięty przez te grzyby podczas przechowywania produktów.

Uzyskane wyniki badań wskazują na wysoki stopień zanieczyszczenia mikrobiologicznego ocenianych herbat ziołowych w saszetkach. Przyczyną tego może być zakażenie roślin już podczas uprawy i zbioru czy też niewystarczające suszenie i długotrwałe przechowywanie surowców w nieodpowiednich warunkach. W magazynach bez wymuszonego obiegu powietrza i kontroli wilgotności względnej szybciej rozwijają się występujące na ziołach mikroorganizmy. Wśród nich często występują toksynotwórcze grzyby, których metabolity są niebezpieczne dla ludzi. Dlatego też na każdym etapie wytwarzania surowce, półprodukty, a następnie gotowe produkty ziołowe powinny być odpowiednio chronione przed zanieczyszczeniami i poddawane ocenie mikrobiologicznej.

\section{Wnioski}

1. Badane herbaty ziołowe w saszetkach charakteryzowały się różnym stopniem zanieczyszczenia mikrobiologicznego, przy czym największą liczbą bakterii, drożdży i grzybów mitosporowych odznaczały się herbaty ziołowe z suszem mięty oraz pokrzywy.

2. Skład jakościowy grzybów wyizolowanych z poszczególnych rodzajów herbat ziołowych w saszetkach był zróżnicowany, ale w każdym z nich największy udział miały grzyby należące do rodzajów Aspergillus, Penicillium i Fusarium.

3. W żadnym $\mathrm{z}$ badanych produktów nie stwierdzono obecności bakterii z rodzaju Salmonella oraz gronkowców koagulazododatnich, natomiast $\mathrm{w}$ herbatach ziołowych z suszem mięty oraz pokrzywy występowały bakterie $E$. coli.

\section{Literatura}

[1] Alwakeel S.S.: The effect of mycotoxins found in some herbal plants on biochemical parameters in blood of female albino mice. Pakistan J. Biol. Sci., 2009, 12 (8), 637-642.

[2] Ashiq S., Hussain M., Ahmad B.: Natural occurrence of mycotoxins in medicinal plants: A review. Fungal Gen. Biol., 2014, 66, 1-10.

[3] Bugno A., Almodovar A.A.B., Pereira T.C., Andreoli Pinto T.J., Sabino M.: Occurrence of toxigenic fungi in herbal drugs. Braz. J. Microbiol., 2006, 37, 47-51.

[4] Cvetnic Z., Pepeljnjak S.: Mycological contamination of stored herbal drugs. Acta Pharm., 1999, 49, 201-209.

[5] Do K.H., An T.J., Oh S.K., Moon Y.: Nation-based occurrence and endogenous biological reduction of mycotoxins in medicinal herbs and spices. Toxins, 2015, 7, 4111-4130.

[6] Farmakopea Polska. Wyd. X. Pol. Tow. Farm., Warszawa 2014.

[7] Koch J., Schrauder A., Alpers K., Werber D., Frank C., Prager R., Rabsch W., Broll S., Feil F., Roggentin P., Bockemühl J., Tschäpe H., Ammon A., Stark K:. Salmonella agona outbreak from contaminated aniseed, Germany. Emerg. Infect. Dis., 2005, 11, 1124-1127. 
[8] Marcinkowska J.: Oznaczanie rodzajów grzybów ważnych w patologii roślin. Fundacja Rozwój SGGW, Warszawa 2004.

[9] Martins H.M., Martins M.L., Dias M.I., Bernardo F.: Evaluation of microbiological quality of medicinal plants used in natural infusions. Int. J. Food Microbiol., 2001, 68, 149-153.

[10] PN ISO 16649-2:2004. Mikrobiologia żywności i pasz. Horyzontalna metoda oznaczania liczby beta-glukuronidazo-dodatnich Escherichia coli. Część 2: Metoda płytkowa w temperaturze 44 stopni $\mathrm{C}$ z zastosowaniem 5-bromo-4-chloro-3-indolilo beta-D-glukuronidu.

[11] PN-EN ISO 6888-1:2001. Mikrobiologia żywności i pasz. Horyzontalna metoda oznaczania liczby gronkowców koagulazo-dodatnich (Staphylococcus aureus i innych gatunków). Część 1. Metoda z zastosowaniem pożywki agarowej Baird-Parkera.

[12] PN-ISO 21527-2:2009. Mikrobiologia żywności i pasz. Horyzontalna metoda oznaczania liczby drożdży i pleśni. Część 2 . Metoda liczenia kolonii w produktach o aktywności wody niższej lub równej 0,95 .

[13] PN-ISO 4833:2004. Mikrobiologia żywności i pasz. Horyzontalna metoda oznaczania liczby drobnoustrojów. Metoda płytkowa w temperaturze 30 stopni C.

[14] PN-EN ISO 6579-1:2017-04. Mikrobiologia łańcucha żywnościowego. Horyzontalna metoda wykrywania, oznaczania liczby i serotypowania Salmonella. Część 1: Wykrywanie Salmonella spp.

[15] Rizzo I., Vedoya G., Maurutto S., Haidukowski M., Varsavsky E.: Assessment of toxigenic fungi on Argentinean medicinal herbs. Microbiological Research, 2004, 159, 113-120.

[16] Romagnoli B., Menna V., Gruppioni N., Bergamini C.: Aflatoxins in spices, aromatic herbs, herbteas and medicinal plants marketed in Italy. Food Control, 2007, 18, 697-701.

[17] Samson R.A., Hoekstra E.S., Frisvad J.C., Filtenborg O.: Introduction to food- and airborne fungi. $6^{\text {th }}$ Ed. Centraalbureau voor Schimmelcultures, Utrecht 2000.

[18] Steinka I., Misiewicz Ł., Kukułowicz A., Ćwikliński M., Dmowski P., Sznajdrowska A.: Próba oceny jakości mikrobiologicznej wybranych suszy roślinnych stosowanych jako używki i preparaty o znaczeniu leczniczym. Zesz. Nauk. Akademii Morskiej w Gdyni, 2011, 68, 13-20.

[19] Stević T., Pavlović S., Stanković S., Šavikin K.: Pathogenic microorganisms of medicinal herbal drugs. Arch. Biol. Sci., 2012, 64 (1), 49-58.

[20] St-Germain G., Summerbell R.: Identifying filamentous fungi. Star, Belmont 2011.

[21] Tosun H., Arslan R.: Determination of aflatoxin B1 levels in organic spices and herbs. Sci. World J. Article, 2013, ID 874093.

[22] Tournas V.H., Katsoudas E.J.: Microbiological quality of various medicinal herbal teas and coffee substitutes. Microbiol. Insights., 2008, 1, 47-55.

[23] Wilson C., Dettenkofer M., Jonas D., Daschner F.D.: Pathogen growth in herbal teas used in clinical settings: A possible source of nosocomial infection? Am. J. Infect. Control, 2004, 32, 117-119.

[24] Wójcik-Stopczyńska B., Jakowienko P., Jadczak D.: Ocena mikrobiologicznego zanieczyszczenia świeżej bazylii i mięty. Żywność. Nauka. Technologia. Jakość, 2010, 4 (71), 122-131.

\section{ASSESSMENT OF MICROBIOLOGICAL QUALITY OF HERBAL TEAS IN SACHETS}

\section{S u m m a ry}

The objective of the research study was to determine the microbial contamination of herbal teas in sachets available in the retail outlets in Lublin and the qualitative composition of mitosporic fungi occurring therein. The study involved 7 types of herbal teas from the following plants: lemon balm (Melissa officinalis), nettle, mint, fennel, linden, chamomile, and sage. Under the experiment, the following was determined: total number of bacteria, yeast, mitosporic fungi, and Escherichia coli bacteria; the analysis was performed to detect Salmonella and staphylococci coagulase $(+)$. It was found that the total number of aerobic mesophilic bacteria, yeast, and mitosporic fungi ranged between: $10^{3}-10^{6}, 10^{3}-10^{4}$, and $10^{2}-10^{5} \mathrm{cfu} \cdot \mathrm{g}^{-1}$, respectively. The herbal teas in sachets and containing nettle and mint showed the highest 
contamination by bacteria and mitosporic fungi, and those teas did not meet the microbiological purity requirements as set in the Polish Pharmacopoeia X. The qualitative composition of mitosporic fungi in the dried herbs tested varied; they all belonged to 10 species such as Alternaria, Aspergillus, Botrytis, Cladosporium, Fusarium, Mucor, Penicillium, Phoma, Rhizopus, and Trichoderma. In all the herbal tea samples tested, fungi of the genera: Aspergillus, Fusarium, and Penicillium prevailed. The sanitary/ hygienic condition of the nettle and mint tea raised major concerns for $E$. coli bacteria were detected therein at a level of $10^{2} \mathrm{cfu}^{-\mathrm{g}^{-1}}$. No Salmonella and staphylococci coagulase $(+)$ were detected in the samples tested.

Key words: dried herbs, microbiological quality, bacteria, yeast, mitosporic fungi 